\title{
The Bag Cells of Aplysia as a Multitransmitter System: Identification of Alpha Bag Cell Peptide as a Second Neurotransmitter
}

\author{
Karen A. Sigvardt, ${ }^{1}$ Barry S. Rothman, Richard O. Brown, and Earl Mayeri \\ Department of Physiology, School of Medicine, University of California, San Francisco, \\ San Francisco, California 94143
}

The bag cell neurons of the marine mollusk, Aplysia, are a putative multitransmitter system that utilizes two or more peptide transmitters derived from a common precursor protein. Two putative transmitters are egg-laying hormone (ELH), a 36 amino acid peptide that induces egg laying and mediates bag cellinduced excitatory effects on certain abdominal ganglion neurons, and $\alpha$-bag cell peptide ( $\alpha$ BCP), which mimics bag cell-induced inhibition of the left upper quadrant (LUQ) neurons and the depolarization of the bag cells that occurs during the bag cell burst discharge. $\alpha$ BCP was previously purified from bag cell extracts in three neuroactive forms: $\alpha B C P(1-9)$, a nine amino acid peptide encoded on the ELH/BCP precursor protein, and two $\mathrm{NH}_{2}$-terminal fragments, $\alpha \mathrm{BCP}(1-8)$ and $\alpha B C P(1-7)$. Analyzing bag cell-induced inhibition of LUQ neurons, we report here that $\alpha B C P$ fulfills the main criteria for transmitter identification: (1) stimulation of individual bag cells produces inhibition of the neurons; (2) inhibitory activity is present in releasate collected following an elicited bag cell burst discharge in the presence of protease inhibitors; (3) $\alpha \mathrm{BCP}(1-9)$ and $\alpha B C P(1-8)$ are detected in the releasate in the presence of protease inhibitors; (4) $\alpha B C P$ is rapidly inactivated after release, as indicated by the lack of detectable $\alpha \mathrm{BCP}$ or inhibitory activity in the releasate in the absence of protease inhibitors, and by the increase in potency of the arterially perfused peptide in the presence of protease inhibitors; (5) $\alpha \mathrm{BCP}$ and the endogenously released transmitter produce apparently identical changes in membrane conductance; (6) bag cell-induced inhibition is reduced or abolished following desensitization of the inhibitory response by long-term application of high concentrations of $\alpha B C P$.

The results provide additional evidence that the bag cells are a multitransmitter system and also suggest that many of the physiological properties of $\alpha B C P$-mediated neurotransmission differ from those of ELH. First, unlike ELH, $\alpha B C P$ is rapidly inactivated after release. Second, $\alpha B C P(1-9)$ may be activated by carboxypeptidase cleavage since $\alpha \mathrm{BCP}(1-8)$ and $\alpha \mathrm{BCP}(1-7)$ are 30 and $10 \times$ as potent, respectively, as $\alpha B C P(1-9)$. Third, the inhibitory action of $\alpha \mathrm{BCP}$ on its targets has a more rapid onset and a shorter time course than the excitatory actions of ELH. Thus, $\alpha$ BCP may diffuse to less distant targets than ELH and serve to regulate the more rapidly occurring neural events underlying egg-laying behavior.

Received Apr. 19, 1985; revised Aug. 5, 1985; accepted Aug. 6, 1985.

Supported by NIH Grant NS16490. We thank Steinhart Aquarium, San Francisco, for kindly providing aquarium facilities.

Correspondence should be addressed to Karen A. Sigvardt, Department of Neurology, University of California, Davis, VAMC, 150 Muir Rd., Martinez, CA 94553.

Present address: Department of Neurology, University of California, Davis, VAMC, 150 Muir Road, Martinez, CA 94553.

Copyright (C) 1986 Society for Neuroscience $0270-6474 / 86 / 030803-11 \$ 02.00 / 0$
Studies in both vertebrates and invertebrates suggest that many types of neurons contain more than one biologically active peptide that are thought to function as neurohormones or neurotransmitters (Erichsen et al., 1982; Hunt et al., 1981; Lundberg et al., 1982; Rothman et al., 1983a; Schultzberg et al., 1980; Watson et al., 1978). The bag cells of Aplysia are a convenient system for investigating the role of peptidergic neurons in the processing of information in the CNS. A bag cell-specific gene encodes a precursor protein that contains the sequences for egglaying hormone (ELH), $\alpha$-bag cell peptide ( $\alpha \mathrm{BCP})$, acidic peptide (AP), $\beta-, \gamma-$, and $\delta \mathrm{BCP}$, and several other peptides (Scheller et al., 1983a). There is strong evidence that ELH, a 4400 Da peptide, mediates two types of bag cell-induced excitatory responses in abdominal ganglion neurons (Branton et al., 1978; Mayeri and Rothman, 1982a; Mayeri et al., 1985), but does not mediate other bag cell-induced responses. $\alpha \mathrm{BCP}$ is a candidate as a second bag cell transmitter for mediating the inhibitory responses (Rothman et al., 1983a).

There are neurons in other parts of the CNS that are immunoreactive for ELH (Chiu and Strumwasser, 1981), and ELH may mediate effects on other central neurons, most notably identified buccal ganglion neurons (Stuart and Strumwasser, 1980). Bag cell-induced responses on a subpopulation of abdominal ganglion neurons provide a convenient preparation for understanding how various bag cell peptides act. Bag cellinduced inhibition occurs in the left upper quadrant (LUQ) neurons, the right upper quadrant white cells R3-R14, and in L14A-C, L10, and other identified and unidentified neurons (Mayeri et al., 1979a, b). The LUQ neurons, which were used previously as an assay system in the isolation and sequencing of $\alpha \mathrm{BCP}$, were used in the present study to further elucidate the role of $\alpha \mathrm{BCP}$. The suggestion that $\alpha \mathrm{BCP}$ is a neurotransmitter is based on the following evidence: (1) Three neuroactive forms of $\alpha \mathrm{BCP}$ have been isolated from bag cell extracts: $\alpha \mathrm{BCP}(1-9)$, (1-8), and (1-7) (Rothman et al., 1983a). The scquence of $\alpha \mathrm{BCP}(1-9)$ is Ala-Pro-Arg-Leu-Arg-Phe-Tyr-Ser-Leu; $\alpha \mathrm{BCP}(1-$ 8) and $\alpha \mathrm{BCP}(1-7)$ are $\mathrm{NH}_{2}$-terminal fragments lacking the $\mathrm{COOH}$-terminal leucine and serylleucine residues, respectively. (2) The three forms of $\alpha \mathrm{BCP}$ mimic inhibition of LUQ neurons and depolarization of the bag cells. Although they differ in their relative potencies, the three forms otherwise produce apparently identical effects on nerve cells. $\alpha \mathrm{BCP}(1-7)$, purified from bag cell extracts, and synthetic $\alpha \mathrm{BCP}(1-7)$ have identical inhibitory actions on LUQ neurons at a given concentration (Rothman et al., 1983a). (3) $\alpha \mathrm{BCP}$ acts directly on LUQ neurons (Rothman et al., 1983a). (4) $\alpha \mathrm{BCP}(1-9)$ is encoded on the bag cell gene between basic residues that represent cleavage sites (Scheller et al., 1983a). (5) Immunohistochemical studies using affinity-purified antibodies to $\alpha \mathrm{BCP}(1-9)$ show that the somata of the left and right upper quadrant neurons are surrounded by an extensive network of $\alpha \mathrm{BCP}(1-9)$-immunoreactive bag cell processes 
that terminate in the ganglionic sheath and are coextensive with bag cell processes immunoreactive for ELH (Pulst et al., 1985).

We present here further evidence that $\alpha \mathrm{BCP}$ fulfills the major criteria for identification as a transmitter and provide additional documentation of the physiological characteristics of $\alpha \mathrm{BCP}$. We find that the physiological characteristics of $\alpha \mathrm{BCP}$ differ in important ways from those of ELH and provide a rationale for why it is functionally useful for a group of neurons to use more than one transmitter derived from a common precursor.

\section{Materials and Methods}

\section{Electrophysiology and arterial perfusion of peptides}

Experiments were carried out on over 100 preparations of Aplysia californica obtained from Sea Life Supply (Sand City, CA). The results of each of the physiological experiments described below were obtained on at least three different preparations. Electrophysiology and arterial perfusion of peptides were performed as described previously (Mayeri and Rothman, 1982b; Mayeri et al., 1979a, b; 1985). In bricf, an abdominal ganglion was dissected from animals weighing 400-1500 gm and pinned in a $1 \mathrm{ml}$ capacity chamber. The preparation was steadily superfused with locally obtained seawater containing $10 \mathrm{mM}$ HEPES (pH 7.6) and $1 \mathrm{gm} / \mathrm{liter}$ dextrose at a rate of $30 \mathrm{ml} / \mathrm{hr}$. In experiments using low $\mathrm{Ca}^{2+}$ high $\mathrm{Mg}^{2+}$ bathing medium, the seawater was replaced with a solution containing $220 \mathrm{~mm} \mathrm{MgCl}_{2}, 1.0 \mathrm{mM} \mathrm{CaCl}_{2}, 228 \mathrm{~mm} \mathrm{NaCl}$ and $10 \mathrm{~mm} \mathrm{KCl}$. Experiments were performed at room temperature $\left(19-23^{\circ} \mathrm{C}\right)$, which usually did not vary more than $1^{\circ}$ in a single experiment. Intracellular recordings were made from up to four neurons simultaneously, using conventional methods. The bag cells were continuously monitored during all experiments by placing an extracellular recording electrode on one or both bag cell clusters.

Solutions of the various peptides to be tested were perfused through the caudal artery of the abdominal ganglion at a rate of $3 \mu \mathrm{l} / \mathrm{min}$ by means of a micrometer syringe. The peptides to be tested were dissolved in filtered $(0.22 \mu \mathrm{m}$ pore size $)$, buffered seawater. Unless noted, the perfusion medium also contained a mixture of protease inhibitors (see below). In all experiments, an aliquot of the perfusion medium without the peptide(s) was applied before the test solution both as a control and to preincubate the ganglion in protease inhibitors. In experiments in which protease inhibitors were not used, BSA $(250 \mu \mathrm{g} / \mathrm{ml})$ was added to the perfusion medium as a carrier. Neither the protease inhibitors alone nor the BSA alone affected target neuron activity, $\alpha \mathrm{BCP}(1-7),(1-$ 8 ), and (1-9), and $\beta-, \gamma-$, and $\delta B C P$ were synthesized by Peninsula Laboratories (Belmont, CA). The serial perfusion experiments were performed as described previously (Mayeri et al., 1985).

\section{Protease inhibitors in the perfusion medium}

In most physiological experiments, the perfusion medium contained $100 \mu \mathrm{M} \mathrm{Na}$ ascorbate, $25 \mu \mathrm{g} / \mathrm{ml}$ angiotensin-converting enzyme inhibitor (Peninsula Laboratories), and $250 \mu \mathrm{g} / \mathrm{ml}$ of each of the following protease inhibitors: bacitracin (Sigma), ovoinhibitor (Sigma; hen egg-white trypsin inhibitor), ovomucoid (Worthington), lima bean trypsin inhibitor (Sigma), leupeptin (Peninsula Laboratories), antipain (Peninsula Laboratories), and phenylalanylalanine (Vega Chemicals). In some earlier experiments, two of the protease inhibitors, angiotensin-converting enzyme inhibitor and phenylalanylalanine, were not included.

In the experiments in which releasate was collected for high-pressure liquid chromatography (HPLC) analysis, the perfusion medium consisted of bathing medium containing $3 \mathrm{~mm} \mathrm{NaHCO}$ and $62 \mu \mathrm{g} / \mathrm{ml}$ each of leupeptin, antipain, diprotin A (Peninsula Laboratories), serylleucine, leucylarginine, and phenylalanylalanine (Vega Biochemicals, Tucson, AZ).

The two groups of protease inhibitors, which were chosen to protect $\alpha \mathrm{BCP}$ from degradation, are known to be effective against several of the major classes of proteases, including aminopeptidases (bacitracin, diprotin A), endopeptidases (ovoinhibitor, ovomucoid inhibitor, leupeptin, antipain), and carboxypeptidases (angiotensin-converting enzyme inhibitor and the dipeptides).

\section{HPLC analysis of releasate}

An abdominal ganglion was placed in a small sealed chamber of 200 $\mu \mathrm{l}$ dead volume. The caudal artery was cannulated and bag cell activity was monitored with two extracellular electrodes, one on each cluster.
The two electrodes also served as stimulating electrodes (Mayeri et al., 1985). The ganglion was perfused through the cannula and superfused by means of a second tube entering the chamber. The perfusion and superfusion rates were each $250 \mu \mathrm{l} / \mathrm{hr}$. Releasate (combined perfusate/ superfusate) was led out of the chamber and collected at $0^{\circ} \mathrm{C}$. Control releasate was collected for $30 \mathrm{~min}$ prior to initiation of a bag cell burst discharge; bag cell burst releasate was collected for 30 min following burst initiation. Releasates were stored at $-20^{\circ} \mathrm{C}$. For analysis, control releasates from six ganglia were pooled to yield approximately $2.1 \mathrm{ml}$; bag cell burst releasates (eight bag cell bursts in six ganglia) were also pooled to yield a total volume of $2.75 \mathrm{ml}$.

Releasate was thawed and applied to a reverse-phase HPLC column (Supelco, $\mathrm{LC}_{18} \mathrm{DB}, 4.6 \times 250 \mathrm{~mm}$ plus $4.6 \times 20 \mathrm{~mm}$ precolumn) equilibrated in pyridine acetate $(0.11 \mathrm{M}$ pyridine, $0.5 \mathrm{~m}$ acetic acid), $\mathrm{pH}$ 4.0. Flow rate was $0.6 \mathrm{ml} / \mathrm{min}$. Peptides were eluted with a complex gradient of $n$-propanol in pyridine acetate, pH 4.0 (see Fig. $6 D$ ).

\section{Results}

\section{Direct bag cell stimulation produces inhibition}

During a bag cell burst discharge, the approximately 400 cells within each cluster fire nearly synchronously for about $20 \mathrm{~min}$ (Kupfermann and Kandel, 1970), producing prolonged inhibition of the LUQs (Mayeri et al., 1979a). The usual method for triggering this burst is by focal stimulation of the bag cell cluster with a short ( $1-2 \mathrm{sec})$ train of electrical pulses via an extracellular electrode placed directly on the surface of either cluster (Mayeri et al., 1979a). The stimulus intensity is carefully adjusted to a level that produces a spike or depolarizing response in the bag cells without producing synaptic potentials or other responses in abdominal ganglion neurons recorded intracellularly. The presence of postsynaptic potentials one-for-one with the stimulus in other ganglion neurons indicates that the stimulus has excited other axons in the connective in addition to bag cell neurons. Although it is probable that this procedure activates only bag cells, it has not been directly demonstrated that the inhibition of the LUQs is due to bag cell activation and not to other neurons that might be activated by the extracellular stimulating electrode.

To test directly for bag cell-induced inhibition, a bag cell and an LUQ neuron were recorded from simultaneously. As shown in Figure $1 A$, direct depolarization of the bag cell by a train of intracellular depolarizing current pulses $(100 \mathrm{msec}$ pulses at $5 / \mathrm{sec}$ ) resulted in repetitive spike activity in the bag cell and inhibition of the LUQ neuron. The repetitive spike activity was most likely restricted to one or a few bag cells of the entire cluster because no spikes were recorded by an extracellular electrode placed on the cluster (not shown). The inhibition was characterized by hyperpolarization of the cell membrane potential, slowing of the cell's bursting pacemaker activity, and a decrease in the spike amplitude. When depolarizing current was again injected into the bag cell, as shown in Figure $1 B$ (arrow), it was then sufficient to initiate the bag cell burst discharge in cells of both bag cell clusters; this resulted in a large and prolonged inhibition of L6. The larger amplitude and longer time course of this response presumably reflects a larger quantity of transmitter released during the burst of the entire bag cell population. Intracellular stimulation of a single bag cell after the end of a long bag cell burst (Fig. $1 B$, right) did not result in further inhibition, apparently because transmitter is no longer released from the bag cells. It did not result from desensitization, since, in other experiments, arterially perfused $\alpha \mathrm{BCP}$ applied following the end of a bag cell burst discharge still resulted in inhibition of the LUQs.

The ability to trigger a bag cell burst discharge by intracellular current injection into a single bag cell neuron is most likely the result of two processes acting together: electrical coupling between bag cells, allowing injected current to spread throughout the population (Kupfermann and Kandel, 1970), and autoex- 


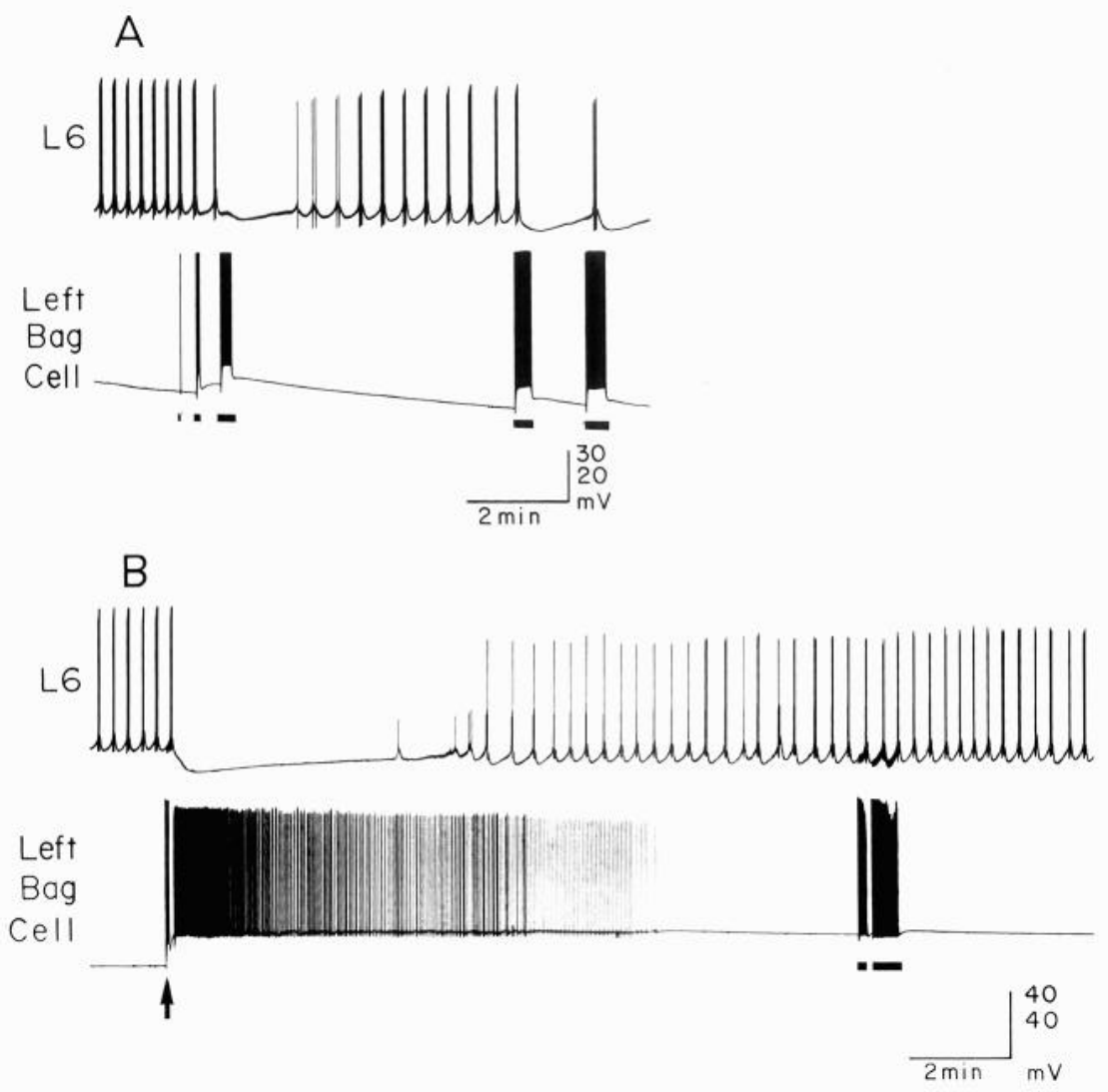

Figure 1. Inhibition of the bursting pacemaker neuron, L6, produced by direct depolarization of a bag cell. L6 and a bag cell in the left bag cell cluster were recorded simultaneously with intracellular microelectrodes. A, Repeated activation of impulses in a single bag cell by intracellular current injection (bars) produced inhibition of L6. B, Brief intracellular current injection into a single bag cell (at arrow) initiated a burst discharge, which occurred in all the cells of the bag cell cluster and resulted in more prolonged inhibition of L6. Minutes later (at right), repeated activation of impulses in the single bag cell produced no effect on L6.

citation by $\alpha \mathrm{BCP}$, in which $\alpha \mathrm{BCP}$ released by bag cells further depolarizes them (Rothman et al., 1983a). Activation of a bag cell burst by this method produced the same effects in the LUQs (and other recorded ganglion neurons) as that produced by carefully controlled extracellular focal stimulation (for example, see Fig. 3, Mayeri et al., 1979a), thus confirming the results obtained by the latter method. Not every bag cell, when activated individually, produced an inhibitory effect; bag cells located closer to target cells seemed to be more effective.

\section{Only $\alpha B C P$ produces inhibition of $L U Q S$}

$\alpha \mathrm{BCP}$ is one of several peptides encoded on the ELH precursor gene (Scheller et al., 1983a). Five of these peptides (ELH, AP, $\alpha-, \beta-$, and $\gamma \mathrm{BCP}$ ) have been isolated from bag cell extracts and identified (ELH, Chiu et al., 1979; AP, Scheller et al., 1983a; $\alpha-, \beta$-, and $\gamma$ BCP, Rothman et al., 1983a, 1985b). The amino acid sequences of $\beta$ - and $\gamma \mathrm{BCP}$ are Arg-Leu-Arg-Phe-His and Arg-Leu-Arg-Phe-Asp, respectively. $\alpha-, \beta$-, and $\gamma \mathrm{BCP}$ have a common sequence of four residues. Because of their structural similarity, it is important to know whether $\beta \mathrm{BCP}, \gamma \mathrm{BCP}$, or the other peptides have an effect on the LUQ neurons. When a solution containing $1 \mu \mathrm{M}$ each of ELH, AP, $\beta$-, $\gamma-$, and $\delta$-bag cell peptide was arterially perfused into the abdominal ganglion, there was no effect on the LUQ neurons (Fig. 2A). Furthermore, concentrations of these peptides as high as $100 \mu \mathrm{M}$, applied individually, had no effect on LUQs (not shown). When $\alpha \mathrm{BCP}(1-$ 7) was added to the solution containing the five other bag cell peptides and perfused, the LUQs were inhibited (Fig. 2B). $\alpha \mathrm{BCP}(1-7)$, applied alone, had the same effect (for example, see Fig. $3 B$ ). Therefore, the inhibition of the LUQs produced by the bag cell discharge is mimicked only by $\alpha$-bag cell peptide.

It was previously shown that the effects of arterially perfused $\alpha \mathrm{BCP}$ on all four LUQ cells ended within a few minutes after the end of application (Rothman et al., 1983a). Thus, the peptide

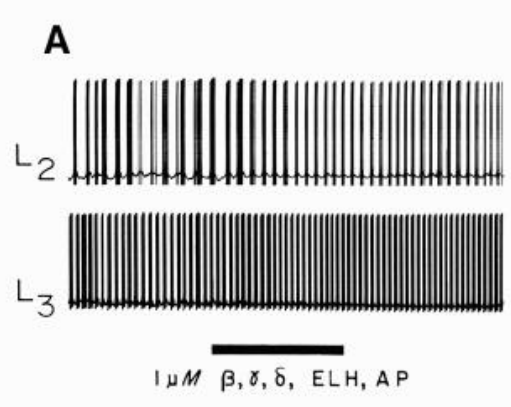

B

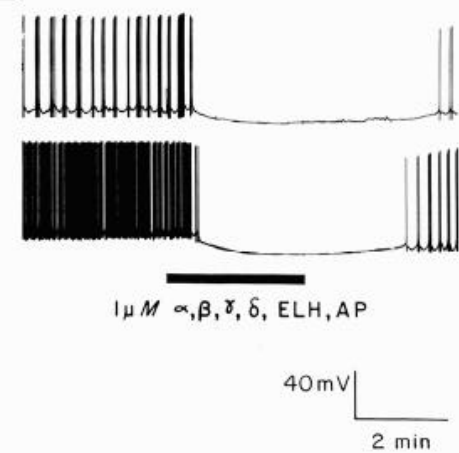

Figure 2. Of six of the peptides encoded on the bag cell precursor gene, only $\alpha \mathrm{BCP}$ produces inhibition of the LUQs. Two LUQ neurons, L2 and $\mathrm{L} 3$, were recorded simultaneously. $A$, Arterial perfusion of a solution containing $1 \mu \mathrm{M}$ each of $\beta-, \gamma-$, and $\delta B C P, E L H$, and $A P$ during the time indicated by the bar had no effect on either neuron. $B$, Addition of 1 $\mu \mathrm{M} \alpha \mathrm{BCP}(1-7)$ to the solution described in $A$ resulted in inhibition similar to that produced by bag cell activation as shown, for example, in Figure 1. 
A

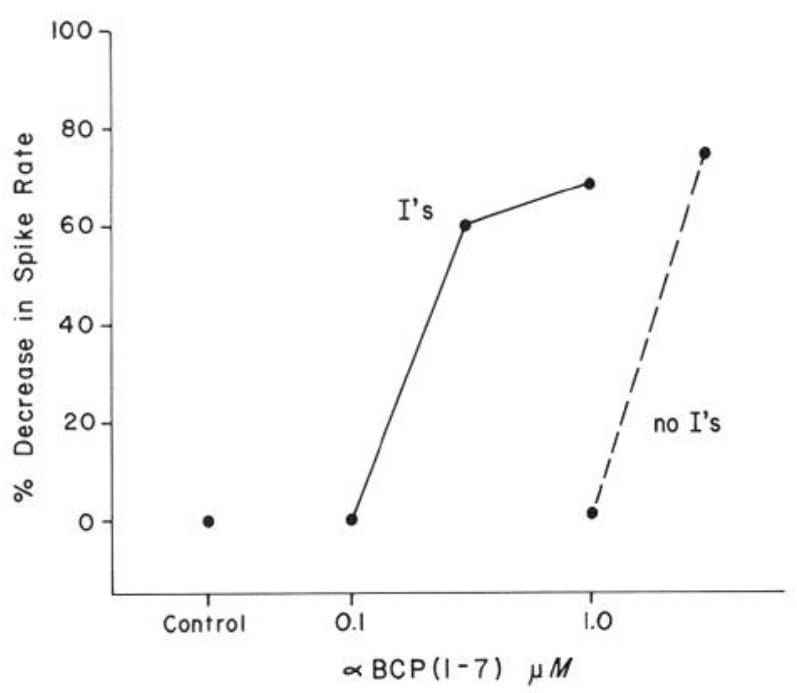

B

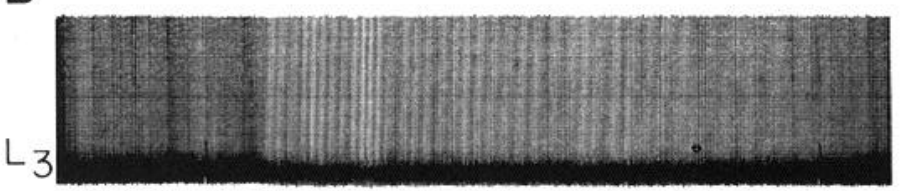

$1 \mu M \propto B C P(1-7)$, No I's

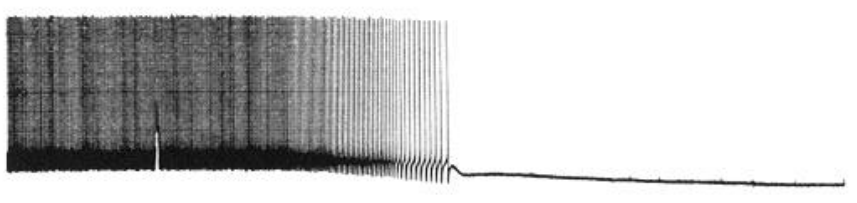

$I \mu M \propto B C P(1-7)+I ' s$

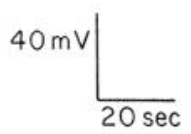

Figure 3. Effects of the presence of protease inhibitors in the perfusate on the potency of arterially perfused $\alpha \mathrm{BCP}(1-7)$. $A$, Percentage decrease in spike rate of an LUQ neuron, L3, versus the concentration of $\alpha \mathrm{BCP}(1-$ 7) in the perfusion medium. Dashed line, No protease inhibitors in the perfusate; solid line, eight protease inhibitors (see Materials and Methods) added to the perfusate. With protease inhibitors (I's), $0.3 \mu \mathrm{M} \alpha \mathrm{BCP}(1-$ 7) produced strong inhibition. Without protease inhibitors (no I's), a concentration between 1.0 and $3.0 \mu \mathrm{M} \alpha \mathrm{BCP}(1-7)$ was necessary to produce the same effect. $B$, Intracellular record from $\mathrm{L} 3$, the activity of which is plotted in $A$, shows that arterial perfusion of $1 \mu \mathrm{M} \alpha \mathrm{BCP}(1-7)$ without protease inhibitors did not affect the neuron's activity, whereas perfusion of the same concentration with protease inhibitors added caused a large inhibition. Arterial perfusion of a solution containing only the protease inhibitors had no effect on the cell's activity (not shown).

mimics all aspects of bag cell-induced inhibition in L2 and L4 and all but the duration of inhibition in cells L3 and L6 (see Discussion). In the present study, we found that the long duration of inhibition was not mimicked by any of the three forms of $\alpha \mathrm{BCP}$ applied singly or in combination with other bag cell peptides $(\beta-, \gamma-$, or $\delta \mathrm{BCP}, \mathrm{ELH}$, or AP). It may be that the longer
A

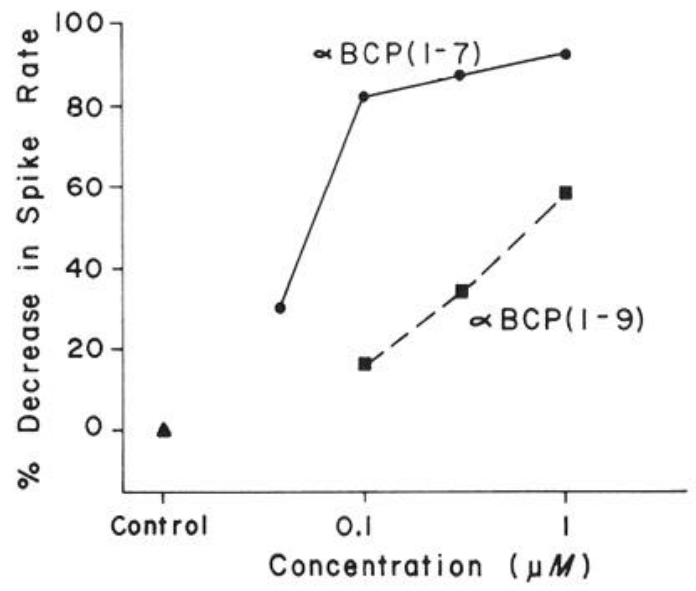

B

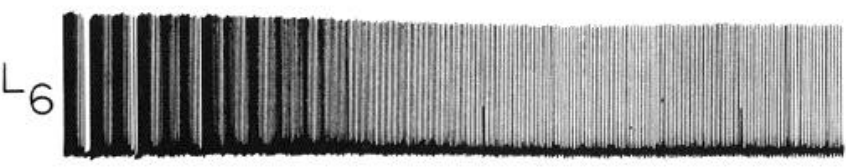

$0.1 \mu M \propto B C P(1-9)$

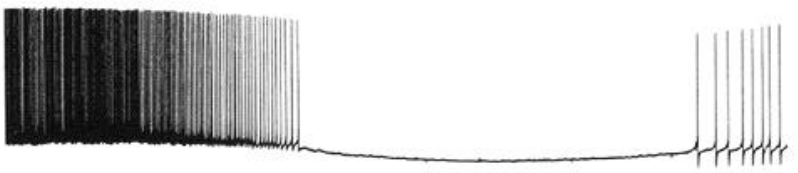

$0.1 \mu M \propto B C P(1-7)$

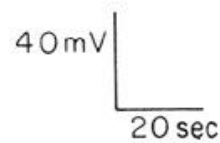

Figure 4. $\alpha \mathrm{BCP}(1-7)$ is about $10 \times$ more potent than $\alpha \mathrm{BCP}(1-9)$. A, Percentage decrease in mean spike rate from control rate of LUQ neuron L6 versus concentration of peptide in the perfusate. The spike rate at each concentration was the average of $4 \mathrm{~min}$ before and after application of the peptide. Solid line, $\alpha \mathrm{BCP}(1-7)$; dashed line, $\alpha \mathrm{BCP}(1-9)$. The effect of $\alpha \mathrm{BCP}(1-9)$ at $0.3 \mu \mathrm{M}$ was about the same as the effect of $\alpha \mathrm{BCP}(1-7)$ at $0.03 \mu \mathrm{M}$, and $1.0 \mu \mathrm{M} \alpha \mathrm{BCP}(1-9)$ had less effect than $0.1 \mu \mathrm{M} \alpha \mathrm{BCP}(1-$ 7). $B$, Intracellular record from $L 6$, whose activity is plotted in $A$, shows that arterial perfusion (indicated by bar) of $0.1 \mu \mathrm{M} \alpha \mathrm{BCP}(1-7)$ produced complete inhibition, whereas the same concentration of $\alpha \mathrm{BCP}(1-9)$ produced only a slight decrease in spike activity.

duration response in L 3 and L6 is produced by a second, as yet unidentified, transmitter released by the bag cells that acts together with $\alpha \mathrm{BCP}$ to prolong the inhibitory response. In other experiments, with pressure application of $\alpha \mathrm{BCP}$ onto L3 from a micropipette placed directly over the soma, we confirmed that the action of $\alpha \mathrm{BCP}$ is direct (Rothman et al., 1983a). This indicates that there are receptors for the transmitter on the neuron's soma. 


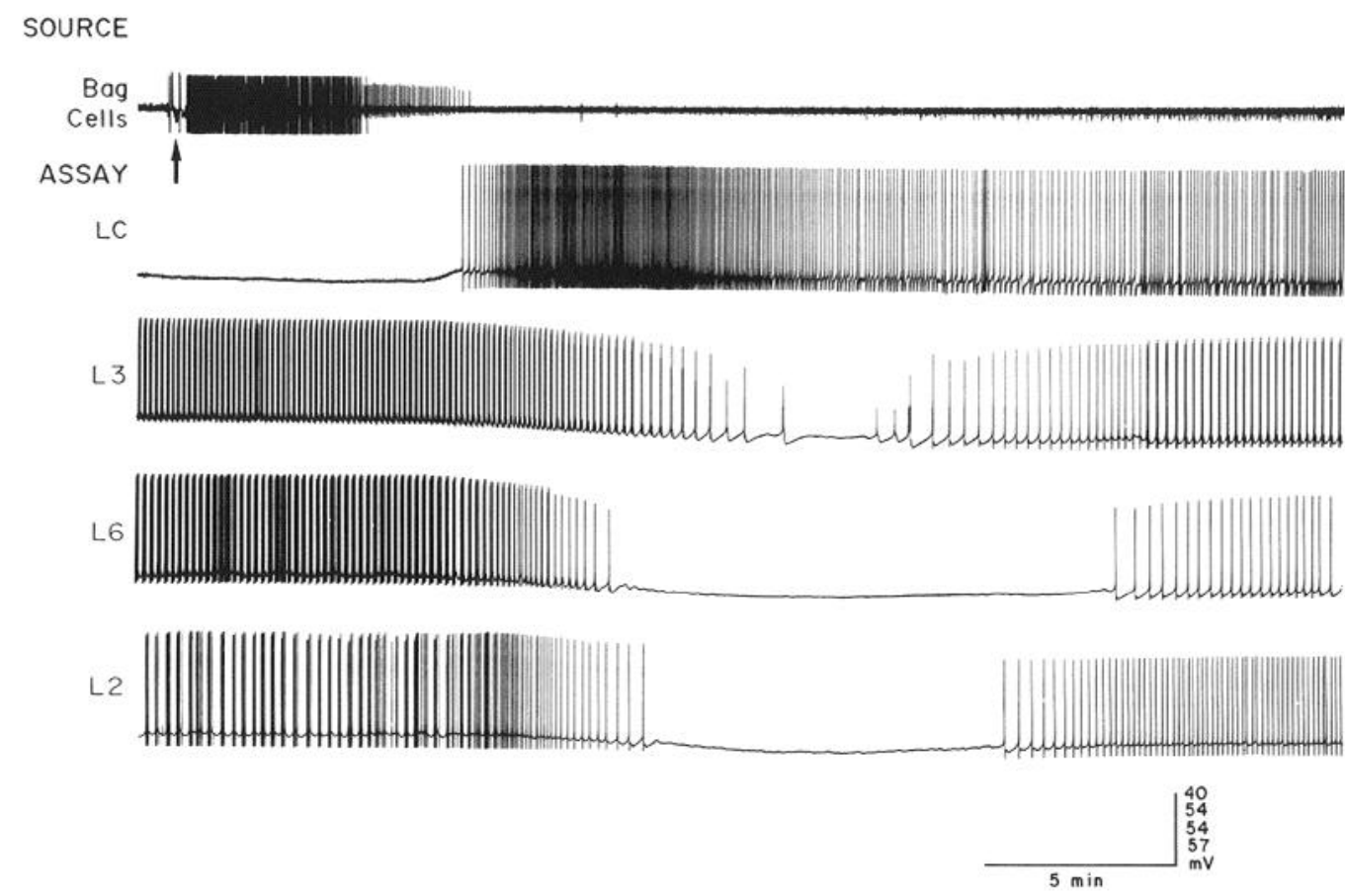

Figure 5. Inhibition of LUQ neurons produced by releasate from stimulated bag cells, provided that protease inhibitors are present. An abdominal ganglion was placed in a small "source" chamber with extracellular electrodes for stimulating and recording from the bag cell cluster. A second abdominal ganglion was placed in an "assay" chamber for simultaneous intracellular recording from three LUQ neurons (L2, L6, and $L 3)$ and a left lower quadrant neuron, $L C$. The source ganglion was simultaneously perfused and superfused with a solution containing protease inhibitors, and the combined perfusate/superfusate was fed directly into the caudal artery of the assay ganglion. An electrically triggered bag cell burst in the source ganglion (arrow) resulted in prolonged inhibition of the LUQs and prolonged excitation of the LC neuron in the assay ganglion.

\section{$\alpha B C P$ is rapidly inactivated in the abdominal ganglion}

Inactivation of $\alpha \mathrm{BCP}$ can be demonstrated by comparing the potency of the peptide in the presence or absence of protease inhibitors in the perfusate (Fig. 3). The graph in Figure $3 \mathrm{~A}$ plots the percentage decrease in spike rate of L 3 from control levels as a function of $\alpha \mathrm{BCP}$ concentration. With protease inhibitors in the perfusate, a concentration of $0.3 \mu \mathrm{M} \alpha \mathrm{BCP}(1-7)$ produced strong inhibition of L3. Without protease inhibitors, an approximately 10 -fold higher concentration of peptide was necessary to produce the same effect. Intracellular recordings from the same experiment (Fig. $3 B$ ) show the effects on L3 of arterially perfusing $1 \mu \mathrm{M}$ concentrations of $\alpha \mathrm{BCP}(1-7)$ with and without inhibitors. In the presence of protease inhibitors, the cell was strongly inhibited, whereas in their absence, the cell was unaffected, indicating that the peptide had been rapidly inactivated. A similar result was obtained for $\alpha \mathrm{BCP}(1-9)$ (not shown); $\alpha \mathrm{BCP}(1-8)$ was not tested. These results suggest that there are membrane-bound proteases in the vascular and interstitial spaces of the ganglion that are highly effective in inactivating $\alpha \mathrm{BCP}$.

\section{$\alpha B C P(1-7)$ is about 10 times more potent than $\alpha B C P(1-9)$}

Of the three forms of $\alpha \mathrm{BCP}, \alpha \mathrm{BCP}(1-8)$ has been shown to be approximately $3 \times$ more potent than $\alpha \mathrm{BCP}(1-7)$ in producing inhibitory effects on the LUQs, and $\alpha \mathrm{BCP}(1-9)$ has been reported to be the least potent (Rothman et al., 1983a). We confirm here that the largest of the peptides, $\alpha \mathrm{BCP}(1-9)$, is the least potent form; it is approximately one-tenth as potent as $\alpha \mathrm{BCP}(1-$ 7) (Fig. 4). The graph in Figure $4 A$ plots the percentage decrease from control levels in spike activity in L6 versus the concentration of peptide in the perfusate. The peptides were applied in the presence of protease inhibitors. The effects of $\alpha \mathrm{BCP}(1-$ 9) at 0.3 and $1.0 \mu \mathrm{M}$ were equal to or smaller than the effects of $\alpha \mathrm{BCP}(1-7)$ at 10 -fold lower concentrations. At $0.1 \mu \mathrm{M}$ (Fig. $4 B$, from the same experiment), L6 was only slightly inhibited by $\alpha \mathrm{BCP}(1-9)$, while at the same concentration of $\alpha \mathrm{BCP}(1-7)$, the cell was nearly maximally inhibited. All three forms of $\alpha \mathrm{BCP}$ produce apparently identical inhibition.

\section{Inhibitory activity is released during the bag cell burst}

If $\alpha \mathrm{BCP}$ is released from the bag cells, one might expect to detect it and its activity in releasate (i.e., perfusate plus superfusate) collected from an abdominal ganglion following a bag cell burst discharge. To test for release, an abdominal ganglion was placed in a small, sealed chamber and simultaneously perfused and superfused, and bag cell activity was monitored with an extracellular electrode. The medium exiting the chamber was fed directly into the artery of a second abdominal ganglion, located in a normal recording chamber, and the activity of neurons was monitored intracellularly. In an earlier study, following a bag cell burst in the first ganglion, releasate produced excitatory responses mediated by ELH in LB and LC cells and R15 in the second ganglion. However, no effects were seen on target neurons that are normally inhibited (LUQ neurons) or transiently excited (L1, R1) by the bag cells (Mayeri et al., 1985, Fig. 6b). We reasoned that, if the inhibition and transient excitation were indeed mediated by bag cell peptides, these peptides may have been inactivated by proteolysis before leaving the ganglion.

To test this possibility, we repeated the experiment just described, but added eight protease inhibitors to the perfusate. (See Materials and Methods; either BSA or three inhibitorsbacitracin, ovomucoid, and lima bean trypsin inhibitor-were used by Mayeri et al., 1985.) During a 60 min control period before the bag cell discharge, the neurons fired at a steady rate. Six minutes after a discharge was triggered in the first ganglion (Fig. 5), cells L2, L3, and L6 in the assay ganglion were inhibited, 


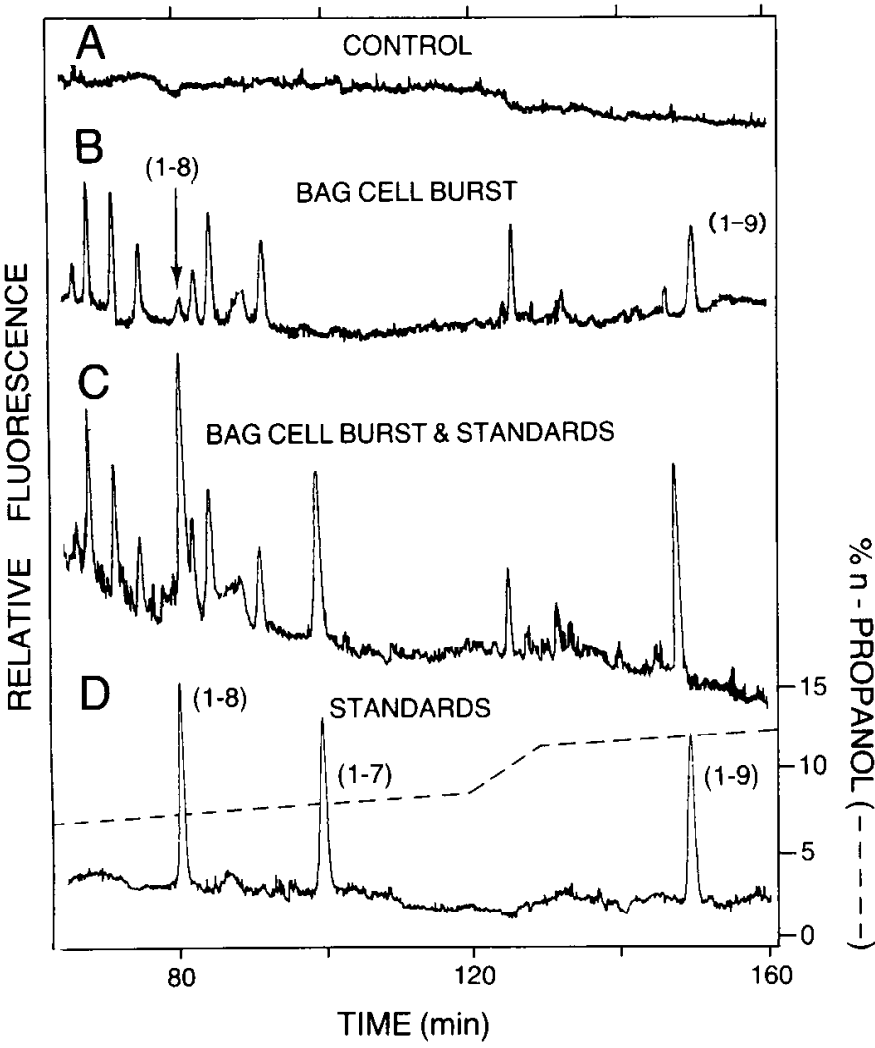

Figure 6. Identification of two forms of $\alpha \mathrm{BCP}$ in relcasatc from stimulated bag cells by HPLC analysis at pH 4.0. Gradient of $n$-propanol used to elute peptides is shown in $D$ (dashed line) and is the same for each record. $A$, Analysis of $320 \mu \mathrm{l}$ of pooled control releasate collected before a bag cell burst discharge shows no detectable peptides. $B$, Analysis of $320 \mu \mathrm{l}$ of pooled releasate collected after a bag cell burst reveals 13 peaks of peptide, including $\alpha \mathrm{BCP}(1-8)$ and $\alpha \mathrm{BCP}(1-9)$, which were identified on the basis of the analyses shown in $C$ and $D$. The $\alpha \mathrm{BCP}(1-$ 8) peak contained $20 \mathrm{ng}$ of peptide, and the $\alpha \mathrm{BCP}(1-9)$ peak contained $96 \mathrm{ng}$. $C$, Analysis of $320 \mu \mathrm{l}$ of the pooled releasate used in $B$ with 128 ng each of $\alpha \mathrm{BCP}(1-7),(1-8)$, and (1-9) standards added. Note that peaks corresponding to $\alpha \mathrm{BCP}(1-8)$ and (1-9) become larger than in the analysis shown in $B$, and that no peak of $B$ coelutes with the $\alpha \mathrm{BCP}(1-7)$ standard. $D$, Analysis of $167 \mathrm{ng}$ each of synthetic $\alpha \mathrm{BCP}(1-7),(1-8)$, and (1-9).

and a left lower quadrant neuron (LC) was excited. These results suggest that the inhibitory transmitter (or transmitters) is a peptide and that, unlike ELH, it is normally completely inactivated by proteolysis before leaving the ganglion.

The interval between the onset of the burst discharge and the onset of depolarization in the LC cell (Fig. 5) corresponded to the time required to pump the releasate from the first to the second ganglion. The magnitude of the responses of the LUQs (and the initial few minutes of the response of the LC cell) to the releasate was greater than the reponse to a bag cell burst normally seen in a single ganglion in the presence of the protease inhibitors. We attribute the greater magnitude of the responses to two factors. First, in the release experiments, the bag cell transmitters were collected and fed directly into the vascular spaces of the second ganglion. In contrast, in the single ganglion experiments, the ganglion was superfused in such a way that the released transmitters were carried by bulk flow rostrally away from the caudally located target cells, which would tend to reduce the amount of bag cell transmitter that reaches the target cells. Second, in the release experiments, the bag cell transmitters were released into space with a much smaller volume than in single-ganglion experiments. As a consequence of both factors, there may have been a higher concentration of transmitter
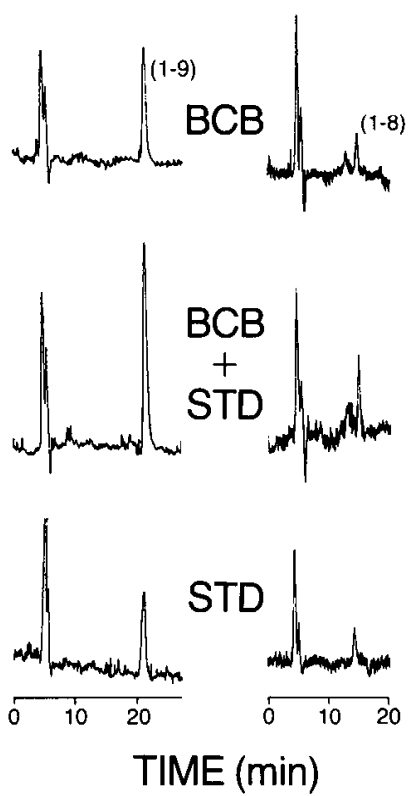

Figure 7. Coelution of released $\alpha \mathrm{BCP}(1-8)$ and $\alpha \mathrm{BCP}(1-9)$ with standards on HPLC at a second $\mathrm{pH}, \mathrm{pH} 2.4$. Pooled releasate, $2.2 \mathrm{ml}$, collected after a bag cell burst $(B C B)$ was purified from the same material and under the same conditions used in the analysis shown in Figure $6 B$. Peaks of purified material corresponding to $\alpha \mathrm{BCP}(1-8)$ and $(1-9)$ were compared to standards (STD) by isocratic analysis on HPLC. Left traces, Analysis of $\alpha \mathrm{BCP}(1-9)$ in $12.7 \% n$-propanol in 0.127 м pyridine, $0.45 \mathrm{M}$ acetic acid, $0.147 \mathrm{M} \mathrm{H}_{3} \mathrm{PO}_{4}$. All samples were injected in a volume of $200 \mu$ l. Top, $\alpha \mathrm{BCP}(1-9)$ purified from releasate (approximately 120 $\mathrm{ng}$ ); middle, $120 \mathrm{ng}$ of $\alpha \mathrm{BCP}(1-9)$ from releasate mixed with $90 \mathrm{ng}$ of synthetic standard elute as a single peak; bottom, $90 \mathrm{ng}$ of $\alpha \mathrm{BCP}(1-9)$ synthetic standard. Right traces, Analysis of $\alpha \mathrm{BCP}(1-8)$ in $9.2 \% n$-propanol in $0.127 \mathrm{M}$ pyridine, $0.45 \mathrm{M}$ acetic acid plus $0.147 \mathrm{M} \mathrm{H}_{3} \mathrm{PO}_{4}$. All samples were injected in a volume of $150 \mu \mathrm{l}$. Top, $\alpha \mathrm{BCP}(1-8)$ purified from releasate (approximately $25 \mathrm{ng}$ ); middle, $25 \mathrm{ng} \alpha \mathrm{BCP}(1-8)$ from releasate mixed with $25 \mathrm{ng}$ of synthetic standard coelute; bottom, $25 \mathrm{ng}$ of $\alpha \mathrm{BCP}(1-8)$ synthetic standard.

reaching the target neurons in the serial perfusion experiments, particularly in the first few minutes, although the precise concentrations cannot be determined. The initial increase in LC firing (mediated by ELH; see Mayeri et al., 1985) was followed by a decrease in firing not normally seen in response to a bag cell burst in a single ganglion. The decrease in firing rate is attributable to an inhibitory effect of $\alpha \mathrm{BCP}$ on these cells due to a high concentration of $\alpha B C P$ (see below).

In the experiment shown in Figure 5, an extracellular recording showed that no bag cell activity occurred in the second ganglion. In three of six experiments, however, a bag cell burst discharge was initiated in the second ganglion within 1-3 min after onset of inhibition evoked by releasate from the first ganglion. This result is consistent with the proposal that $\alpha \mathrm{BCP}$ and/ or other bag cell peptides are excitatory autotransmitters involved in the initiation and maintenance of the burst discharge within each cluster (Rothman et al., 1983a).

$\alpha B C P$ is released during the bag cell burst

Release experiments were conducted on six abdominal ganglia in order to determine if $\alpha \mathrm{BCP}$ was present in the releasate. Perfusate collected before the bag cell burst in each experiment was pooled, as was the releasate collected in each experiment after the initiation of a bag cell burst discharge. The perfusate contained six protease inhibitors that were compatible with the HPLC analysis (see Materials and Methods). Peptides present in pooled releasate were analyzed by HPLC using a complex 


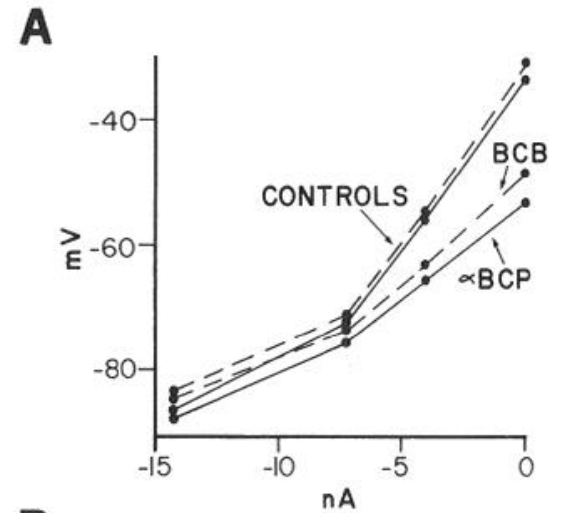

B
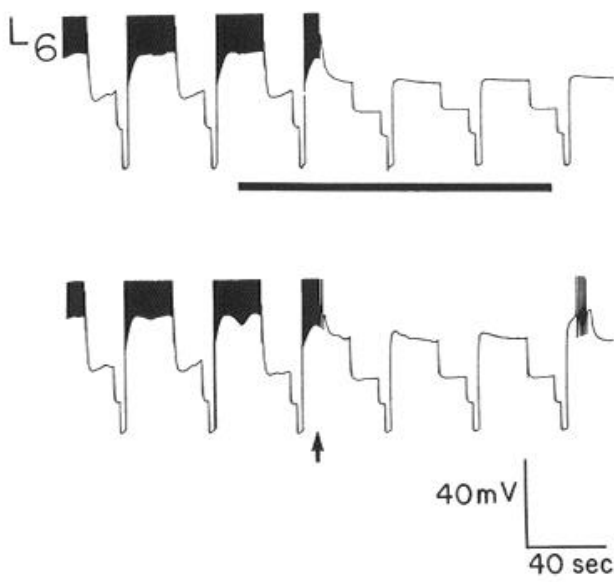

Figure 8. Identity of action of $\alpha \mathrm{BCP}$ and the endogenously released bag cell inhibitory transmitter. A three-step hyperpolarizing current pulse was periodically applied to LUQ neuron L6. A, Membrane voltage versus steady-state current measured at the end of each step of current. Current-voltage relationships are shown for control conditions and after arterial perfusion of $\alpha B C P$ (solid lines) or control conditions and after an electrically triggered bag cell burst ( $B C B$; dashed lines). The data points for $\alpha B C P$ and $B C B$ were each taken from the three-step current pulse that occurred during the peak of the inhibitory response. The data points for the control are averages from three current pulses just prior to the inhibitory response. (The data points for the control membrane potential at $0 \mathrm{nA}$ were taken at the inflection point on the upswing of the membrane potential between two successive action potentials.) $\alpha \mathrm{BCP}$ and the BCB produced apparently identical changes in the currentvoltage relationship, indicating the ionic mechanisms underlying the two responses are identical. $B$, Intracellular record of $\mathrm{L} 6$, from which data in $A$ are taken. Upper record, Inhibitory response after application of $\alpha \mathrm{BCP}(1-7)$ (bar). Lower record, Inhibitory response following an electrically triggered bag cell response (arrow; tops of spikes are not shown).

gradient of $n$-propanol in pyridine acetate at pH 4.0. A 94 min segment of a $270 \mathrm{~min}$ elution profile of four test solutions is presented in Figure 6. Analysis of $320 \mu \mathrm{l}$ of pooled control releasate collected before the bag cell burst discharge showed no detectable material (Fig. $6 \mathrm{~A}$ ). (The protease inhibitors in the releasate eluted prior to the segment shown.) The limit of detection was $10 \mathrm{ng}$.

Analysis of pooled releasate collected following the initiation of the bag cell burst discharge showed at least 13 peaks of material (Fig. $6 B$ ). Two peaks eluted at times close to those of the $\alpha \mathrm{BCP}(1-9)$ and $\alpha \mathrm{BCP}(1-8)$ standards (Fig. $6 D$ ), suggesting that these two peptides were present in the releasate. To confirm the identity of these two peaks, $128 \mathrm{ng}$ of each $\alpha \mathrm{BCP}$ standard was added to the pooled releasate and analyzed on HPLC. As seen

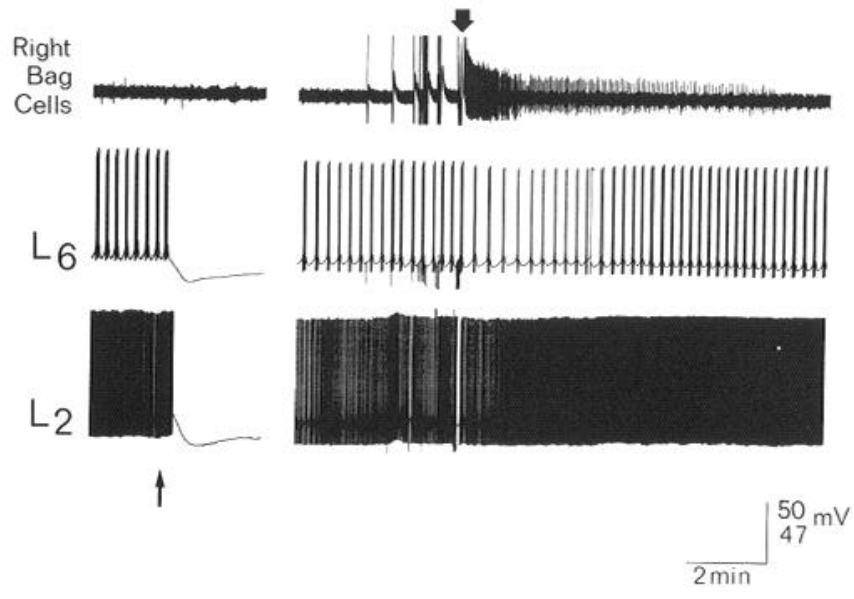

Figure 9. Cross-desensitization of inhibitory responses produced by $\alpha \mathrm{BCP}$ and bag cell activity. When LUQ cells are desensitized by prolonged application of $\alpha \mathrm{BCP}$ at high concentration, the inhibition normally produced by a bag cell burst is reduced or abolished. Simultaneous recordings from right bag cell cluster (extracellular recording) and LUQ neurons, L2 and L6 (intracellular recordings). Left, Onset of continuous arterial perfusion of $1 \mathrm{mM} \alpha \mathrm{BCP}(1-7)$ for 30 min (beginning at lower arrow), which initially caused inhibition of the LUQ cells. Right, After $25 \mathrm{~min}$, with $\alpha \mathrm{BCP}$ still present in the perfusate, activity had returned to baseline, indicating that the LUQ cells had become desensitized. An electrically triggered bag cell burst (beginning at upper arrow) resulted in a lack of inhibitory response in L2 and a greatly reduced inhibitory response in L6.

in Figure $6 C$, the endogenous peptide and exogenous $\alpha \mathrm{BCP}(1-$ 9) standard eluted as a single peak at $148 \mathrm{~min}$. [The $\alpha \mathrm{BCP}(1-$ 9) peak occurred $2.5 \mathrm{~min}$ earlier in the run shown in Fig. $6 B$ than the corresponding peaks in Fig. $6, B$ and $D$ because of small variations in the elution profile over such long-lasting gradients. $\alpha \mathrm{BCP}(1-7)$ elutes $1 \mathrm{~min}$ earlier in Fig. $6 C$ than in Fig. $6 D$, and the peak eluting at $127 \mathrm{~min}$ in Fig. $6 \mathrm{~B}$ elutes 2 min earlier in Fig. $6 C$.] The small peak of material thought to be $\alpha \mathrm{BCP}(1-8)$ apparently eluted with the peak of the $\alpha \mathrm{BCP}(1-8)$ standard, but because the amount of standard was over 8 -fold greater than endogenous peptide, precise co-elution could not be unequivocally demonstrated in this analysis. No peak in the pooled releasate (Fig. $6 B$ ) eluted close to the time of the $\alpha \mathrm{BCP}(1-7)$ standard, indicating that it was not present in the releasate in detectable amounts. Subsequent peaks (data not shown) were identified as AP and ELH on the basis of comigration with AP and ELH, which were purified and identified from bag cell extracts (Mayeri et al., 1985; Rothman et al., 1985b). ELH and $\mathrm{AP}$, but not $\alpha \mathrm{BCP}(1-9,1-8$, nor 1-7), were detected in releasate without protease inhibitors (unpublished observations).

An additional comigration experiment was done to confirm the identification of $\alpha \mathrm{BCP}(1-8)$ and (1-9) in the releasate. Material corresponding to the elution times of $\alpha \mathrm{BCP}(1-9)$ and (18 ) was purified from $2.2 \mathrm{ml}$ of pooled releasate from the same experiment by preparative HPLC under the same conditions as the analysis above. The purified material was again compared to standards on HPLC, but at $\mathrm{pH} 2.4$ instead of $\mathrm{pH} 4.0$, and under isocratic conditions instead of a gradient (Fig. 7). The material corresponding to $\alpha \mathrm{BCP}(1-9)$ eluted at the same time as an $\alpha \mathrm{BCP}(1-9)$ standard, and the standard and endogenous peptides eluted together as a single peak. Similar results were obtained for $\alpha \mathrm{BCP}(1-8)$ at a lower isocratic concentration of $n$-propanol (Fig. 7, right traces).

The amount of $\alpha \mathrm{BCP}$ present in releasate was estimated by comparisons of peak heights in releasate and standards. There was $96 \mathrm{ng}$ of $\alpha \mathrm{BCP}(1-9)$ and $20 \mathrm{ng}$ of $\alpha \mathrm{BCP}(1-8)$ in $320 \mu \mathrm{l}$ of 

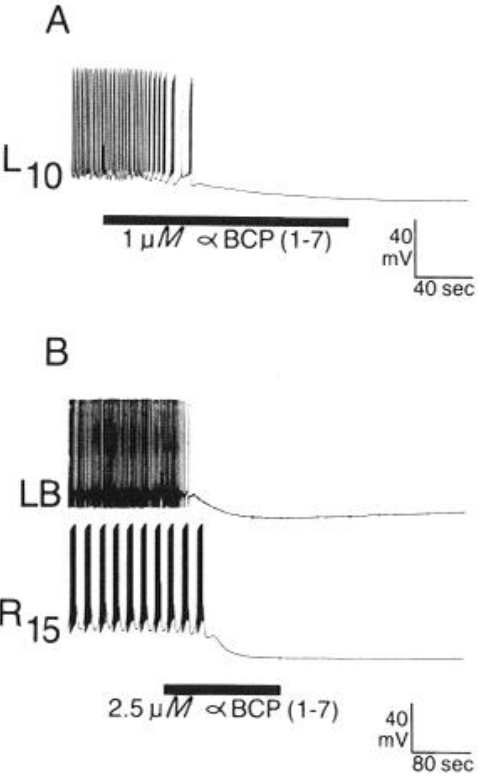

Figure 10. Inhibition of various identified cells by arterial perfusion of $\alpha \mathrm{BCP}(1-7)$. $A$, Inhibition of L10. B, Inhibition of an LLQ cell $(L B)$ and $\mathrm{R} 15$.

pooled releasate (Fig. $6 \mathrm{~B}$ ), which corresponds to 103 and $21 \mathrm{ng}$, respectively, per bag cell burst. These amounts are in good agreement with the amounts recovered from purification of releasate. Of the $660 \mathrm{ng}$ of $\alpha \mathrm{BCP}(1-9)$ expected, $540 \mathrm{ng}$ were recovered; of the $138 \mathrm{ng}$ of $\alpha \mathrm{BCP}(1-8)$ expected, $50 \mathrm{ng}$ were recovered.

These results indicate that some, if not all, $\alpha \mathrm{BCP}$ is originally cleaved from the ELH/BCP precursor and released from bag cells as a 9 amino acid peptide. $\alpha \mathrm{BCP}(1-8)$ may be released simultaneously with $\alpha \mathrm{BCP}(1-9)$. Alternatively, only $\alpha \mathrm{BCP}(1-9)$ is released and subsequently converted to $\alpha \mathrm{BCP}(1-8)$ and perhaps $\alpha \mathrm{BCP}(1-7)$ by carboxypeptidase cleavage after release. Our data do not distinguish between these two possibilities (see Discussion).

\section{$\alpha B C P$ and the endogenous inhibitory transmitter produce the} same conductance change in target neurons

When arterially perfused at an appropriate concentration, $\alpha \mathrm{BCP}$ mimics the time course of onset and the magnitude of hyperpolarization that occurs in LUQ cells in response to a bag cell burst discharge (Rothman et al., 1983a). To test whether the effects of the exogenously applied peptide and the endogenously released transmitter on membrane conductance are identical, the membrane potential reponse to three levels of imposed hyperpolarizing current was measured following perfusion of $\alpha \mathrm{BCP}(1-7)$ and compared to the response following a subsequent bag cell burst discharge (Fig. 8). The data from a typical $(n=7)$ experiment (shown in Fig. $8 B$ ) are graphed in Figure $8 A$. Each $I-V$ plot in Figure $8 A$ is constructed from a single, threestep current pulse and represents the steady-state current-voltage characteristic of the target cell membrane at the time each current pulse was applied. The $I-V$ plots for $\alpha \mathrm{BCP}$ application and bag cell burst were constructed from the three-step current pulse that was applied during the peak of the hyperpolarizing response. The shift in the $I-V$ plot away from the control levels was similar following application of $\alpha \mathrm{BCP}$ and discharge of the bag cells, suggesting that the change in the ionic conductances underlying the hyperpolarizing response is the same in both cases. As shown in Figure $8 B$, under control conditions, the first three current pulses produced stable changes in the membrane potential. Application of $\alpha \mathrm{BCP}$ (upper trace) and stimulation of the bag cells (lower trace) produced similar hyperpolarizing re- sponses. In each case, the current-voltage relationship plotted from the current pulse applied during the peak of the hyperpolarizing response changed from control in an identical manner, and these changes were maintained during the two subsequent current pulses. The changes from control produced by the first $(-4 \mathrm{nA})$ step are the most prominent, though there are also changes for the other two steps. The change in the slope of the $I-V$ curves in each case (Fig. $8 A$ ) indicates that there is an increase in membrane conductance with a reversal potential that extrapolates to near $-80 \mathrm{mV}$, the equilibrium potential for potassium. The results are consistent with an earlier study indicating that bag cell-induced inhibition of LUQ cells is caused by a conductance increase to potassium ions plus a second hyperpolarizing mechanism that is relatively independent of membrane conductance (Brownell and Mayeri, 1979).

\section{Desensitization of the bag cell-induced response by prior application of $\alpha B C P$}

At present, an antagonist to the binding of $\alpha \mathrm{BCP}$ to cell receptors has not been developed. In lieu of an antagonist, a cross-desensitization experiment was performed to test whether the inhibitory responses to the bag cell transmitter and to applied $\alpha \mathrm{BCP}$ are mediated via the same receptor or postreceptor mechanism. If the same receptor mediates both responses, then the bag cell discharge should produce no inhibition when the inhibitory response to $\alpha \mathrm{BCP}$ has been desensitized by prior application of $\alpha \mathrm{BCP}$ at high concentration. $\alpha \mathrm{BCP}$ was therefore applied to the ganglion by continuous arterial perfusion at high concentration $(1 \mathrm{~mm})$ for $30 \mathrm{~min}$, initially producing inhibition of the two LUQ neurons (Fig. 9, left traces beginning at lower arrow). After $25 \mathrm{~min}$ of application, the spontaneous pacemaker activity of the LUQ neurons was at or near their level prior to application of the peptide, indicating that desensitization had occurred (Fig. 9 , right traces). Under these conditions, an electrically triggered bag cell discharge (upper arrow) produced little or no inhibitory response, suggesting that cross-desensitization of the responses had occurred and that the applied $\alpha \mathrm{BCP}$ binds to the same receptors or acts through the same postreceptor mechanism as the transmitter released by the bag cells.

It should be noted that there was a slight response to the bag cell burst that remained after desensitization (Fig. 9, right traces). In L6 (and L3), the bag cell burst produced a slight inhibition, whereas in L2 (and L4) there was actually net excitation. One interpretation of this result is that a second transmitter is involved in mediating bag cell effects on L2 and L4 and that the effects of the second transmitter become apparent only after the response to the first has become desensitized (see Discussion).

\section{Inhibition of other neurons by $\alpha B C P$}

The LUQ neurons were used in the present study as convenient cells in which to study the role of $\alpha \mathrm{BCP}$ in mediating bag cellinduced inhibition. However, a bag cell discharge inhibits other identified and unidentified neurons in the abdominal ganglion, including R2, the right upper quadrant white cells (R3-R14), the ink gland motor neurons (L14A, B, C), and L10 (Mayeri et al., 1979a, b). Unlike the other cells, L10 is transiently inhibited for 5-10 min and then undergoes prolonged excitation (Mayeri et al., 1979b), which is thought to be mediated by ELH (unpublished observations). Arterial perfusion of the abdominal ganglion with $\alpha \mathrm{BCP}$ inhibited L10 (Fig. 10A), R2, and R3-R14 (not shown). Recording from both identified and unidentified neurons, we found that all cells that were inhibited by the bag cells were also inhibited by application of $\alpha \mathrm{BCP}$. This is consistent with the hypothesis that $\alpha \mathrm{BCP}$ is the mediator of all bag cell-induced inhibition in the ganglion. In addition, we found that cells that were excited by the bag cells were inhibited by $\alpha \mathrm{BCP}$. This included left lower quadrant (LLQ) neurons and R15 (Fig. 10B). Although we did not examine the concentration 
dependence of the response of the neurons to $\alpha \mathrm{BCP}$ in detail, it generally paralleled that of $\alpha \mathrm{BCP}$ on LUQ neurons, and like the LUQ cells, the effects ended within a few minutes after the end of application.

The inhibitory actions of $\alpha \mathrm{BCP}$ on cells not normally inhibited by a bag cell burst discharge were reduced or abolished when $\alpha \mathrm{BCP}$ was arterially perfused with ELH. As in an experiment described previously (Scheller et al., 1983b, Fig. 5), we confirmed that arterial perfusion of $1 \mu \mathrm{M}$ each of ELH, $\alpha \mathrm{BCP}$, and acidic peptide (AP) mimicked prolonged excitation of LLQ cells and slow inhibition of L6 and other LUQ cells. We also found that perfusion of this set of peptides mimicked burst augmentation of R15 and depolarization of the bag cells. Thus, for LLQ cells, the hyperpolarizing effect of $\alpha \mathrm{BCP}$ is largely offset by the depolarizing effect of ELH in the first $2.5 \mathrm{~min}$ after the start of arterial perfusion, and after $\alpha \mathrm{BCP}$ is washed away, prolonged excitation by ELH continues. For L6 and other LUQ cells, ELH by itself has no effect except at very high concentrations $(\geq 100 \mu \mathrm{M}$ ), and the response is entirely due to $\alpha \mathrm{BCP}$. None of the three peptides, when applied singly or together, has an effect on Ll or R1 even at very high concentrations ( $\geq 100 \mu \mathrm{M})$.

\section{Discussion}

\section{$\alpha B C P$ is a bag cell neurotransmitter}

The results presented here, together with those previously reported (Rothman et al., 1983a), provide strong evidence that $\alpha \mathrm{BCP}$ is a bag cell neurotransmitter, as follows: (1) Synthesis of the transmitter by the bag cells is supported by purification of large amounts of $\alpha \mathrm{BCP}$ from bag cell extract (Rothman et al., 1983a) and by the molecular genetic data indicating that a bag cell-specific gene codes for a precursor molecule containing the amino acid sequence of $\alpha \mathrm{BCP}(1-9)$ (Scheller et al., 1983a). (2) $\alpha \mathrm{BCP}(1-9)$ immunoreactive terminals are in close association with LUQ cell bodies (Pulst et al., 1985). (3) $\alpha \mathrm{BCP}$ mimics inhibition of L2 and L4 and all but the duration of inhibition of L3 and L6 (see below). (4) $\alpha \mathrm{BCP}$ acts directly on the LUQs to produce the inhibition. (5) The changes in the current-voltage relationship in the LUQs in response to the bag cell burst, and to application of $\alpha \mathrm{BCP}$, are apparently identical, suggesting an identical ionic mechanism of action. The precise underlying ionic mechanisms need to be elucidated by further studies. (6) Inhibitory activity characteristic of $\alpha \mathrm{BCP}$ is released during a bag cell discharge, and an amount of $\alpha \mathrm{BCP}$ consistent with this activity is present in releasate. The amount of $\alpha \mathrm{BCP}$ present in the releasate appears to be sufficient to cause inhibition. More specifically, neurally evoked inhibition can be mimicked by a $10 \mathrm{~min}$ arterial perfusion of $15 \%$ of the amount of $\alpha \mathrm{BCP}(1-9)$ or $2 \%$ of the amount of $\alpha \mathrm{BCP}(1-8)$ detected in the releasate per bag cell burst discharge. (7) Desensitization of the response of the LUQ neurons to applied $\alpha \mathrm{BCP}$ results in reduction or abolition of the response to a subsequently elicited bag cell burst discharge. (8) A mechanism for rapid inactivation (proteolysis) for $\alpha \mathrm{BCP}$ exists.

Thus, the key criteria for identification of a substance as a neurotransmitter have been established for $\alpha \mathrm{BCP}$. Although blockage of the postsynaptic response to cndogenous and cxogenous transmitter was not attempted because of the lack of a specific antagonist, the results of the cross-desensitization experiment suggest that $\alpha \mathrm{BCP}$ may bind to the same receptor as the endogenous transmitter.

$\alpha B C P$ and $E L H$ do not mediate all aspects of bag cell-induced responses

$\alpha \mathrm{BCP}$ and ELH mimic all but two aspects of known bag cellinduced responses: transient excitation of $\mathrm{L} 1$ and $\mathrm{R} 1$, for which $\beta \mathrm{BCP}$ is a candidate transmitter (Rothman et al., 1985a), and the long-lasting aspect of inhibition of L3 and L6. Arterially perfused $\alpha \mathrm{BCP}$ mimics the onset and amplitude of the inhibitory response produced in all the LUQ neurons by a bag cell burst discharge and mimics the duration of the response in L2 and L4; it does not, however, mimic the longer duration of the bag cell-induced response seen in L3 and L6 (Rothman et al., 1983a; and this study). After the initiation of a bag cell burst, all four neurons show the initial hyperpolarizing response that inhibits all spike activity. L2 and L4 return to the baseline membrane potential and firing rate within 1-2 min after the cessation of the bag cell burst, but L3 and L6 exhibit a prolonged inhibitory phase characterized by a sustained hyperpolarization and decrease in the rate of spontaneous spike activity of these neurons for more than $2 \mathrm{hr}$.

The simplest hypothesis for the prolonged inhibition of L3 and L6 is that another transmitter, in addition to $\alpha \mathrm{BCP}$, is released by the bag cells and that the combined effects of the two transmitters produce the prolonged inhibition. This second transmitter might act in either of two ways: (1) to potentiate the inhibitory effect of $\alpha \mathrm{BCP}$ but have no effect by itself or (2) to act similarly to $\alpha \mathrm{BCP}$ but with a more prolonged action. One class of candidates for the second transmitter includes modified forms of $\alpha \mathrm{BCP}$ (e.g., amidated, phosphorylated, or cleaved from the precursor in an extended form). Whatever the nature of the second transmitter, the principal transmitter on LUQs and other inhibited cells is very likely to be $\alpha \mathrm{BCP}$, because it is released in such large amounts.

Physiological characteristics of $\alpha B C P$ differ from those of $E L H$ Compared to ELH, $\alpha \mathrm{BCP}$ has a more rapid onset and a shorter duration of action and is inactivated more rapidly. After the start of the bag cell burst, the onset of inhibition in LUQ cells begins within a few seconds and reaches a maximum in about $30 \mathrm{sec}$ (Mayeri et al., 1979a). In contrast, bag cell-induced responses mediated by ELH are much slower, requiring 1-2 min to result in spike activity in LLQs and $10-15 \mathrm{~min}$ to reach a maximum in R15 (Mayeri et al., 1979a, b). The rates of onset of the responses are mimicked by arterial perfusion of $\alpha \mathrm{BCP}$ and ELH, applied separately or together (Branton et al., 1978; Mayeri et al., 1985; Rothman et al., 1983a; Scheller et al., 1983b). This indicates that, to a considerable degree, the more rapid action of $\alpha \mathrm{BCP}$ results from a faster cellular response once the peptide has reached the cell.

The effects of arterially perfused $\alpha \mathrm{BCP}$ end 1-2 min after pcrfusion is stoppcd, whercas the cffccts of ELH persist for more than an hour (Branton et al., 1978; Mayeri et al., 1985). This suggests that the continued presence of $\alpha \mathrm{BCP}$ near target cells is needed for inhibition to persist for as long as the duration of the bag cell burst, as is the case for inhibition of cells L 2 and L4.

$\alpha \mathrm{BCP}$ is rapidly inactivated after release, as indicated by the lack of detectable $\alpha \mathrm{BCP}$ or inhibitory activity in releasate containing no protease inhibitors, and by the increase in potency of $\alpha \mathrm{BCP}$ when arterially perfused in the presence of protease inhibitors. It seems unlikely that a rapid-uptake system for the peptides could explain these results, since such systems are not known to be inhibited by protease inhibitors. Although direct evidence of proteolytic cleavage is needed before definitive conclusions can be made, the results suggest that there are extracellular proteases bound to connective tissue and/or cell membranes lining the interstitial and vascular spaces of the ganglion and overlying sheath. According to this hypothesis, these proteases totally inactivate $\alpha \mathrm{BCP}$ before the peptide is able to diffuse into the medium surrounding the ganglion, which, in intact animals, corresponds to the general circulation. It is therefore unlikely that $\alpha \mathrm{BCP}$ released from bag cells has any action on tissues outside the abdominal ganglion. This is in sharp contrast to ELH, which is relatively resistant to proteolysis, is easily detected in the bathing medium (Mayeri et al., 1985) and is 
relcased into the general circulation in apparently sufficient amounts to act on other neural tissue (Stuart et al., 1980) and on gonadal tissue (Rothman et al., 1983b). Therefore, the relative susceptibilities of $\alpha \mathrm{BCP}$ and ELH to degradation by extracellular proteolytic enzymes may be important determinants of the distance over which the two peptides can act.

\section{After release, $\alpha B C P$ may diffuse longer distances than conventional synaptic transmitters}

Although $\alpha \mathrm{BCP}$ may diffuse a shorter distance than ELH before being inactivated, there are indications that it diffuses a longer distance from release sites to its targets than conventional synaptic transmitters such as $\mathrm{ACh}$, at the vertebrate skeletal neuromuscular junction. First, in contrast to the discrete IPSPs produced in LUQ cells by the cholinergic neuron, L10, there are no discrete PSPs occurring with each bag cell spike; instead, the inhibitory response produced by the bag cells is slow and smoothly graded, as expected should $\alpha \mathrm{BCP}$ be released from distant sites. Second, the onset of neurally evoked inhibition can be mimicked by diffuse application, as is accomplished by arterial perfusion, whereas focal application of the peptide, which more nearly mimics synaptic release, produces a response that is too rapid to mimic the neurally evoked response. Third, there are large numbers of profusely branched bag cell axons within tens of microns of the nearest neurons, including those inhibited by a bag cell burst. All of these axons are almost certainly release sites for $\alpha \mathrm{BCP}$ since (1) they are immunoreactive for $\alpha \mathrm{BCP}(1-$ 9), (2) large amounts of $\alpha \mathrm{BCP}$ are recovered from bag cell extracts (Rothman et al., 1983a), and (3) large amounts of $\alpha \mathrm{BCP}$ can be detected in the releasate when protease inhibitors are present. Thus, even with rapid proteolysis of the peptide after release, there appears to be enough $\alpha \mathrm{BCP}$ released to reach targets at long distances (as compared to conventional synaptic transmitters) before being completely inactivated.

\section{Selective action of $\alpha B C P$}

Target neurons located in the rostral (LUQ and RUQ cells) and rostroventral (cells L12-L14) regions of the ganglion are inhibited by bag cell activity or by application of $\alpha \mathrm{BCP}$, but are unaffected by ELH at apparently physiological concentrations. On the other hand, the target neurons located in the caudal ganglion (LLQs and R15) are excited by bag cell activity and by application of ELH, but are inhibited when $\alpha \mathrm{BCP}$ is applied. What, then, determines the selectivity of action of $\alpha \mathrm{BCP}$ on neurons within the ganglion; i.e., which cells are ultimately inhibited by it during a bag cell discharge? There are likely to be at least two contributing factors. First, the relatively rapid inactivation of $\alpha \mathrm{BCP}$ following its release may play a role. If one assumes that ELH and $\alpha \mathrm{BCP}$ are released from bag cell axons in equal amounts, then the inhibition of rostrally located neurons and the lack of inhibition of caudally located target neurons can be accounted for by the higher density of bag cell axonal processes in the rostral and rostroventral portions of the ganglion (Chiu and Strumwasscr, 1981; Pulst et al., 1985); cells located closest to densely packed bag cell release sites (e.g., LUQs) will therefore receive higher concentrations of $\alpha \mathrm{BCP}$ than those located near less densely packed sites (e.g., LLQs and $\mathrm{R} 15$ ) because $\alpha \mathrm{BCP}$ is more rapidly inactivated than ELH when diffusing from the release sites to the target cells. Consequently, if most or all cells have the same sensitivity to $\alpha \mathrm{BCP}$, as seems to be the case, then cells located closest to densely packed release sites will be strongly inhibited and cells located farther away will be less inhibited or unaffected by $\alpha \mathrm{BCP}$.

A major determinant of whether a cell is inhibited by $\alpha \mathrm{BCP}$ may therefore be not the presence or absence of $\alpha \mathrm{BCP}$ receptors on the target cells, but the degree to which $\alpha \mathrm{BCP}$ is degraded before reaching the target cell. In contrast, the concentrations of ELH are likely to be higher than $\alpha \mathrm{BCP}$ throughout the gan- glion, and selectivity of the response to ELH is thought to be determined by the presence or absence of ELH receptors on neurons (Mayeri and Rothman, 1982a; Mayeri et al., 1985).

A second factor for determining the selectivity of the various neurons to inhibition by $\alpha \mathrm{BCP}$ may be the presence or absence of ELH receptors on individual neurons and the consequent interaction between $\alpha \mathrm{BCP}$ and ELH on individual target cells where both receptors are present. Cells without high-affinity $\mathrm{ELH}$ receptors (e.g., LUQ cells) are affected only by $\alpha \mathrm{BCP}$, and therefore inhibited. In cells with both ELH and $\alpha \mathrm{BCP}$ receptors, the effects of arterially perfused ELH and $\alpha \mathrm{BCP}$ interact to produce the observed effect. For example, in LLQs, the hyperpolarizing effect of $\alpha \mathrm{BCP}$ appears to sum with or be occluded by the depolarizing effect of ELH to produce net excitation. Summation of effects may also occur in R15, although more data are needed to determine whether additional interactions, such as occlusion or potentiation of the effects of one peptide by the other, also play a role.

If one assumes that bag cell peptides are uniformly processed from a single precursor in the bag cells and released in equimolar amounts to diffuse long distances to their targets (Rothman et al., 1983a), then it may eventually be possible to perfuse equimolar amounts of bag cell neurotransmitters arterially and totally reconstruct the bag cell-induced responses.

\section{Possible activation of $\alpha B C P$ after release}

Of the three neuroactive forms of $\alpha \mathrm{BCP}, \alpha \mathrm{BCP}(1-9)$ was the prevalent form in the releasate (Fig. 6). $\alpha \mathrm{BCP}(1-8)$ was also detected, but not (1-7). This strongly suggests that the (1-9) form is an end product of the processing of the ELH/BCP precursor protein within the bag cells before release. This conclusion is consistent with the finding that the nine-residue peptide is the prevalent form in bag cell extracts when proteolysis is carefully controlled (B. S. Rothman et al., 1985b). It is also consistent with molecular genetic data, which show that the $\alpha \mathrm{BCP}(1-9)$ amino acid sequence that is encoded on the precursor is flanked by presumed cleavage sites consisting of a single arginine residue on the amino terminus and three arginine residues on the carboxy terminus (Scheller et al., 1983a).

Although the releasate contained only one-fifth as much $\alpha \mathrm{BCP}(1-8)$ as (1-9), $\alpha \mathrm{BCP}(1-8)$ was $30 \times$ as potent as (1-9) and therefore represented the major portion of inhibitory activity in the releasate. The presence of $\alpha \mathrm{BCP}(1-8)$ in the releasate presumably results from carboxypeptidase A-like cleavage of the nine-residue form. There are two sites at which this cleavage might occur: either within the secretory granules before release, or in extracellular space after release. Although more data are needed to resolve the issue, we favor the latter possibility, since intragranular cleavage would require a processing step (cleavage of a carboxy-terminal leucine residue) that is not known to occur in secretory granules (Gainer et al., 1985). The proposed activation of $\alpha \mathrm{BCP}$ after release is similar to the activation of the polypeptide hormone, angiotensin II, by converting enzyme, a dipeptidyl carboxypeptidase present in the circulation. The present data provide evidence for similar processing of a neuropeptide in the CNS.

If it does occur after release, the process of activation must occur simultaneously with inactivation. Detection of released $\alpha \mathrm{BCP}$ appeared to require the presence of carboxypeptidase inhibitors in the perfusion medium. This is consistent with the hypothesis that $\alpha \mathrm{BCP}(1-9)$ is activated to (1-8) and even (1-7) by carboxypeptidase activity and then inactivated by continued carboxypeptidase activity to (1-6) and smaller forms. Inactivation is, in addition, likely to involve proteolysis by aminoand/or endo-peptidases, since inhibitors of these two classes of proteases were required to detect released $\alpha \mathrm{BCP}$. Since $\alpha \mathrm{BCP}(1-$ 7) was not detected in the releasate, its contribution as a neurotransmitter remains to be established. However, under the 
experimental conditions used, the lack of $\alpha \mathrm{BCP}(1-7)$ in the releasate may have occurred because the rate of its production from (1-9) and (1-8) was much slower than the rate of inactivation of (1-9) and (1-8) by endo- and/or aminopeptidases.

\section{References}

Branton, W. D., E. Mayeri, P. Brownell, and S. B. Simon (1978) Evidence for local hormonal communication between neurones in Aplysia. Nature 274: 70-72.

Brownell, P., and E. Mayeri (1979) Prolonged inhibition of neurons by neuroendocrine cells in Aplysia. Science 204: 417-420.

Chiu, A. Y., and F. Strumwasser (1981) An immunohistochemical study of the neuropeptidergic bag cells of Aplysia. J. Neurosci. 1:812826.

Chiu, A. Y., M. W. Hunkapiller, E. Heller, D. K. Stuart, L. E. Hood, and F. Strumwasser (1979) Purification and primary structure of the ncuropcptide egg-laying hormone of Aplysia californica. Proc. Natl. Acad. Sci. USA 76: 6656-6660.

Erichsen, J. T., A. Reiner, and H. J. Karten (1982) Co-occurrence of substance P-like and Leu-enkephalin-like immunoreactivities in neurons and fibers of avian nervous system. Nature 295: 407-410.

Gainer, H., J. T. Russell, and Y. P. Joh (1985) The enzymology and intracellular organization of peptide precursor processing: The secretory vesicle hypothesis. Neuroendocrinology 40: 171-184.

Hunt, S. P., P. C. Emson, R. Gilbert, M. Goldstein, and J. R. Kimmel (1981) Presence of avian pancreatic polypeptide-like immunoreactivity in catecholamine and methionine-enkephalin-containing neurons within the central nervous system. Nature 275: 226-228.

Kupfermann, I., and E. R. Kandel (1970) Electrophysiological properties and functional interconnections of two symmetrical neurosecretory clusters (bag cells) of abdominal ganglion of Aplysia. J. Neurophysiol. 33: 865-876.

Lundberg, J. M., T. Hökfelt, A. Änggard, L. Terenius, R. Elde, K. Markey, and M. Goldstein (1982a) Organization principles in the peripheral sympathetic nervous system: Subdivisions by co-existing peptides (somatostatin-, avian pancreatic polypeptide- and vasoactive intestinal polypeptide-like immunoreactive materials). Proc. Natl. Acad. Sci. USA 79: 1303-1307.

Mayeri, E., and B. S. Rothman (1982a) Nonsynaptic peptidergic neurotransmission in the abdominal ganglion of Aplysia. In Neurosecretion-Molecules, Cells and Systems, D. S. Farner and K. Lederis, eds., pp. 307-318, Plenum, New York.

Mayeri, E., and B. S. Rothman (1982b) Peptide effects on molluskan neurons. In Strategies for Studying the Roles of Peptides in Neuronal Function (Short Coursc Syllabus), J. L. Barker, ed., pp. 121-130, Society for Neuroscience, Bethesda, MD.

Mayeri, E., P. H. Brownell, W. D. Branton, and S. B. Simon (1979a) Multiple, prolonged actions on neuroendocrine bag cells on neurons in Aplysia. I. Effects on bursting pacemaker neurons. J. Neurophysiol. 42: 1165-1184.

Mayeri, E., P. H. Brownell, and W. D. Branton (1979b) Multiple, prolonged actions of neuroendocrine bag cells on neurons in Aplysia.
II. Effects on beating pacemaker and silent neurons. J. Neurophysiol 42: 1185-1197.

Mayeri, E., B. S. Rothman, P. H. Brownell, W. D. Branton, and L. Padgett (1985) Nonsynaptic characteristics of neurotransmission mediated by egg-laying hormone in the abdominal ganglion of Aplysia. J. Neurosci. 5: 2060-2077.

Pulst, S., D. Gussman, B. S. Rothman, and E. Mayeri (1985) Colocalization of alpha-bag cell peptide and egg-laying hormone in the abdominal ganglion of Aplysia californica. Soc. Neurosci. Abstr. 11. 481.

Rothman, B. S., E. Mayeri, R. O. Brown, P.-M. Yuan, and J. E. Shively (1983a) Primary structure and neuronal effects of $\alpha$-bag cell peptide, a second candidate neurotransmitter encoded by a single gene in bag cell neurons of Aplysia. Proc. Natl. Acad. Sci. USA 80: 5753-5757.

Rothman, B. S., G. Weir, and F. E. Dudek (1983b) Egg-laying hormone: Direct action on the ovotestis of Aplysia. Gen. Comp. Endocrin. 52: 134-141.

Rothman, B. S., R. H. Scheller, and E. Mayeri (1985a) The bag cell neurons of Aplysia as a possible peptidergic multi-transmitter system: From genes to behavior. In Gene Expression in Brain, C. ZomzelyNeurath and W. A. Walker, eds., pp. 235-274, Wiley, New York.

Rothman, B. S., K. A. Sigvardt, and E. Mayeri (1985b) Co-release of five peptides, ELH, AP, alpha-, beta-, and gamma-BCP, derived from a common precursor protein of the bag cells of Aplysia. Soc. Neurosci. Abstr. 11: 482.

Scheller, R. H., J. F. Jackson, I. B. McAllister, J. H. Schwartz, E. R. Kandel, and R. Axel (1982) A family of genes that codes for ELH, a neuropeptide eliciting a stereotyped pattern of behavior in Aplysia. Cell 28: 707-719.

Scheller, R. H., J. F. Jackson, L. B. McAllister, B. S. Rothman, E. Mayeri, and R. Axel (1983a) A single gene encodes multiple neuropeptides mediating a stereotyped behavior. Cell 32: 7-22.

Scheller, R. H., B. S. Rothman, and E. Mayeri (1983b) A single gene encodes multiple peptide-transmitter candidates involved in a stereotyped behavior. Trends Neurosci. 6: 340-345.

Schultzberg, M., T. Hökfelt, G. Nilsson, L. Terenius, J. F. Rehfeld, M. Brown, R. Elde, M. Goldstein, and S. Said (1980) Distribution of peptide- and catecholamine-containing neurons in the gastro-intestinal tract of rat and guinea-pig: Immunohistochemical studies with antisera to Substance $P$, vasoactive intestinal polypeptide, enkephalins, somatostatin, gastrin/cholecystokinin, neurotensin, and dopamine $\beta$-hydroxylase. Neuroscience $5: 689-744$.

Stuart, D. K., and F. Strumwasser (1980) Neuronal sites of action of a neurosecretory peptide, egg-laying hormone, in Aplysia californica. J. Neurophysiol. 43: 499-519.

Stuart, D. K., A. Y. Chiu, and F. Strumwasser (1980) Neurosecretion of egg laying hormone and other peptides from electrically active bag cell neurons of Aplysia. J. Neurophysiol. 43: 488-498.

Watson, S. J., H. Akil, C. W. Richard III, and J. D. Barchas (1978) Evidence for two separate opiate peptide neuronal systems. Nature 275: 226-228. 